\title{
Quality of Work Life and Employee Performance in Academia
}

\author{
K.R. Bindi and Dr.A. Dharmaraj
}

\begin{abstract}
Success of any organization depends on remaining competitive at all times. But being competitive is very short lived unless achieved through effective and efficient utilization of its manpower which cannot be easily surpassed. Hence it is highly essential that any method designed to improve employee performance be positively perceived especially in academics. The study uses stratified sampling with a sample size of 30 and used SPSS 20 for conducting the statistical analysis like chi-square and ANOVA. The results showed that the psychological factors effect Quality of Work Life and in turn employee performance.
\end{abstract}

Keywords--- Quality of Work Life, Employee Performance.

\section{INTRODUCTION}

$\mathrm{O}$ RGANIZATIONAL success depends on always remaining competitive. Competitiveness may be achieved through operational efficiency, cost reduction, maintaining high quality products, or through effective and efficient utilization of its human resource. Any organization gaining a competitive edge over other companies except through efficient utilization of its employees have a limited time within which they need to take advantage. The time span available for the organization to gain advantage is the time taken by the competitors to catch up. Whereas those organizations gaining competitiveness through its efficient and effective utilization of its employees cannot be surpassed by none other as each organizations employees are its unique assets Indermun, V., \& Saheedbayat, M. (2013). So one can very well say, 'the success of any organization depends upon its employee's performance'. There are several methods and techniques for improving employee's performance. One among them is the Quality in working life provided to the employees by the organization. Any facilities or welfare measure can motivate or satisfy an employee only if he is able to perceive the same. The awareness and acceptance of these facilities depends on each employee's psychological makeup.

\section{Aims OF THE STUDY}

The Quality of work life of employees can be simply understood as the degree to which they are able to satisfy important personal needs through their experiences in the work organization along with achieving organizational goals. It is a multidimensional concept involving the organization, i.e. the employees and management, their facilities, the work content and the working conditions. The QWL programmes

K.R. Bindi, Asst. Professor, SNGIST, N.Paravur \& Research Scholar, Karpagam University, Coimbatore.

Dr.A. Dharmaraj, Associate Professor, Karpagam University. DOI: 10.9756/IJRAS.8154 can provide solutions to several problems faced by educational organization from its employees like lack of job satisfaction, absenteeism, employee turnover, job stress, work stress, breaks in communication networks, work-life balance, positive organizational culture etc. Employee performance is a function of both the individual and the organization. The above two constructs are situational and contextual to the workplace. This means that individuals and organizations are interdependent. Such scenarios demand a fit between the person and the environment. Employees are attracted to the organizations that have characteristics similar to their own and organizations select people who share many common personal attributes. In turn the people in the organization determine the kind of internal environment that defines the organization and it follows that organizations composed of people who fit the organizational environment will be more effective than those in which people and environment do not match. The Quality of work life even though provided equally by the organization will be accepted differently by individual employees. This is due to the psychological makeup of each employee. Psychological makeup of an individual plays a vital role in perceiving about his external environment and influences his behavior. Psychological factors refer to an individual's mental characteristics and attributes that can affect individual behavior. It consists of personality, perception, attitudes, values and learning. Employee performance refers to whether a person performs his job well. Campbell Employee performance is divided in to task specific behavior and nontask specific behavior (contextual and citizenship and counterproductive behavior). The significance of the study being that any individual/ employee with the right psychological makeup will perceive and understand the QWL provided by the organization in the right spirit and thereby be motivated to exhibit better performance. Therefore this study attempts to establish a relationship between the factors influencing the psychological makeup of the individual and the Quality of work life initiatives provided by the organization. The research further attempts to establish relationship between the Quality of work life and the perceived employee performance.

\section{REVIEW OF LITERATURE}

Quality of work life thinking stands at the confluence of two separate streams of thought: one to humanize the workplace and the other to improve productivity. (Walton.R 1973) QWL refers to an individual's perception of and attitudes towards, his or her work and the total working environment. In simple words, QWL can be defined as an individual's evaluative reactions to, and satisfaction with, his/her work and the total working environment (Nadler, D. a. 1983)QWL include job security, better reward systems, higher 
pay, opportunity for growth, and participative groups among others.(Havlovic, S.J.) QWL is the favourable working environment that supports and promotes satisfaction by providing employees with rewards, job security, and career growth opportunities.(Lau, Wong, Chan and Law)QWL is viewed as a wide ranging concept, which includes adequate and fair remuneration, safe and healthy working conditions and social integration in the work organization that enables an individual to develop and use all his or her capacities.( GunaSeelan Rethinam, Maimunah Ismail)Qualitative aspect of working life at the work place is QWL( Saklani D.R.) Loo See Beh in his study on Liking QWL and employee job performance: Implications for organizations found a positive link between QWL and employee performance.There is significant relationship among organizational factors, supervision style, reward system and job design with psychological empowerment.(Dr. Abdul Hassanpoor, Dr. JavadMehrabi et al,2012) Taking empowerment as a motivational and cognitive concept, empowerment is defined as a motivational structure which is based on employees' perception with regard to their work environment.(Parker 1994, Randoff 1995). These days for an organization to be successful and achieve its organizational objectives it is imperative that its employees are satisfied with their work, since work occupies an important place in many people's lives, such conditions are likely to affect not only their physical but also a high level of social, psychological and spiritual well- being. It is well established in the literature that employees with a high level of psychological well-being are better, more committed, and more productive than employees with a low level of psychological well- being(Wright and Bonett2007, Wright and Cropanzano 2004). Nonetheless, employees are likely to have higher well- being if they are satisfied with their work and organization and they perceive their Quality of Work Life positively, since an employee's experiences in the work place and his/her QWL influence his/her health and psychological well-being(Chan and Wyatt 2007, Srivastava 2007). QWL is also found to affect work responses in terms of organizational identification, job satisfaction, job involvement, job effort, job performance, intention to quit, organizational turnover and personal alienation( Carter et al., 1990;Efraty\&Sirgy, 1990; Efraty et al., 1991).

\section{RESEARCH Methodology}

The Psychological factors were grouped as opportunity for growth and job development, supervisor and co-worker relationship, stress, personality, Attitude, Learning, Perception and value systems. These factors were measured using the opportunity to develop ability, promotional chances, helping and accommodative nature of supervisor, disagreement with the supervisor, help received from co-workers, too much work, maintenance of interpersonal relationship in worklife, learning opportunity and its utilization on the job, loyalty, honesty, aversion to job, gratefulness to the organization, the match between organizational values and personal values, stress from supervisor and monotonous nature of job.

The factors assessed for Quality of Work life were organizational recognition, satisfaction with working conditions, work content, job security, welfare measures, external reward and opportunity for future developmental activities.

Employee performance was measured on the basis of quality and quantity of output like target meeting, timely completion of work, wastage of resources and need for redoing of the job etc.

\section{Objectives}

1. To study the different Psychological factors

2. To analyze the impact of Psychological factors on Quality of work Life

3. To analyze the impact of Quality of work Life on Employee performance

\section{Hypothesis of the Study}

1. $\mathrm{HOa}=$ Psychological factors have no impact on Quality of Wok Life

$\mathrm{H} 1 \mathrm{a}=$ Psychological factors have an impact on Quality of Work Life

2. $\mathrm{H} 0 \mathrm{~b}=$ Quality of Work Life has no impact on perceived employee performance

$\mathrm{H} 1 \mathrm{~b}=$ Quality of Work Life have impact on perceived employee performance

The Population for the study included all the faculty members of the educational institution in Kerala and a sample size of 30 was obtained through Stratified simple random sampling. Both Primary and secondary data were used and primary data was collected through questionnaire. Data was analyzed using Average, Percentage, Chi-Square and ANOVA through the software SPSS 18.

\section{DATA ANALYSIS}

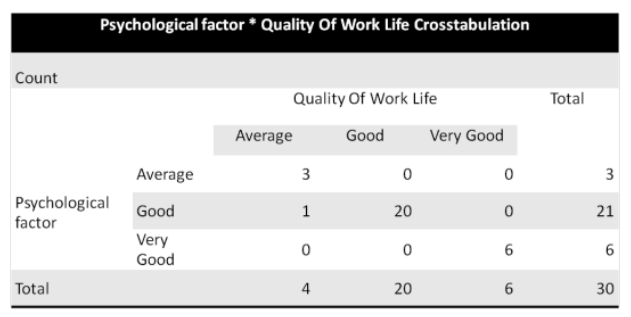

\begin{tabular}{|l|r|r|r|}
\hline \multicolumn{4}{|c|}{ Chi-Square Tests } \\
\hline & \multicolumn{1}{|c|}{ Value } & df & Asymp. Sig. (2-sided) \\
\hline Pearson Chi-Square & $32.962^{\mathrm{a}}$ & 4 & .000 \\
\hline Likelihood Ratio & 27.584 & 4 & .000 \\
\hline Linear-by-Linear Association & 18.632 & 1 & .000 \\
\hline N of Valid Cases & 30 & & \\
\hline
\end{tabular}

The $\mathrm{p}$ value is less than .05. Hence the Null hypothesis is rejected. This means that the psychological factors have an impact on QWL

\begin{tabular}{|l|l|l|l|l|l|}
\hline \multicolumn{6}{|l|}{ Quality Of Work Life * Employee performance Cross tabulation } \\
\hline \multicolumn{7}{|l|}{ Count } & Employee performance & \multirow{2}{*}{ Total } \\
\cline { 3 - 7 } & Average & Good & Very Good & \\
\hline \multirow{3}{*}{ Quality Of Work Life } & Average & 3 & 1 & 0 & 4 \\
\cline { 2 - 7 } & Good & 0 & 19 & 1 & 20 \\
\cline { 2 - 6 } & Very Good & 0 & 0 & 6 & 6 \\
\hline Total & 3 & 20 & 7 & \\
\hline
\end{tabular}




\begin{tabular}{|l|r|r|r|}
\hline & Value & df & $\begin{array}{c}\text { Asymp. } \\
\text { Sig. (2- } \\
\text { sided) }\end{array}$ \\
\hline & & 4 & .000 \\
\hline Pearson Chi-Square & $42.360^{\mathrm{a}}$ & 4 & .000 \\
\hline Likelihood Ratio & 21.454 & 1 & .000 \\
\hline $\begin{array}{l}\text { Linear-by-Linear } \\
\text { Association }\end{array}$ & 14.969 & & \\
\hline N of Valid Cases & 30 & & \\
\hline
\end{tabular}

The p- value is less than0.05. Hence the null hypothesis is rejected. This means that Quality of work life has an impact on Perceived employee performance.

The impact of psychological factor is most significant in the Business Administration ie, 4.33 followed by MCA=3.88 and Engg with 4.10.Regarding Quality of Work Life 4.43,4.33 and 3.82 and Perceived employee performance 4.57,4.33 and 3.88 for respective departments.

Hypothesis for ANOVA were:

- H01: In Psychological factors there is no significant difference between departments.

- H02: In Quality of Work Life there is no significant difference between departments

- $\quad$ H03: In Perceived employee performance there is no significant difference between departments

\begin{tabular}{|c|c|c|c|c|c|c|}
\hline \multicolumn{7}{|c|}{ ANOVA } \\
\hline & & $\begin{array}{l}\text { Sum of } \\
\text { Squares }\end{array}$ & $\mathrm{df}$ & $\begin{array}{l}\text { Mean } \\
\text { Square }\end{array}$ & F & Sig. \\
\hline \multirow[t]{3}{*}{$\begin{array}{l}\text { Psychological } \\
\text { factor }\end{array}$} & $\begin{array}{l}\text { Between } \\
\text { Groups }\end{array}$ & 1.888 & 2 & .944 & 3.741 & .037 \\
\hline & $\begin{array}{l}\text { Within } \\
\text { Groups }\end{array}$ & 6.812 & 27 & .252 & & \\
\hline & Total & 8.700 & 29 & & & \\
\hline \multirow[t]{3}{*}{$\begin{array}{l}\text { Quality Of } \\
\text { Work Life }\end{array}$} & $\begin{array}{l}\text { Between } \\
\text { Groups }\end{array}$ & 2.348 & 2 & 1.174 & 4.217 & .025 \\
\hline & $\begin{array}{l}\text { Within } \\
\text { Groups }\end{array}$ & 7.518 & 27 & .278 & & \\
\hline & Total & 9.867 & 29 & & & \\
\hline \multirow[t]{3}{*}{$\begin{array}{l}\text { Employee } \\
\text { performance }\end{array}$} & $\begin{array}{l}\text { Between } \\
\text { Groups }\end{array}$ & 2.654 & 2 & 1.327 & 5.260 & .012 \\
\hline & $\begin{array}{l}\text { Within } \\
\text { Groups }\end{array}$ & 6.812 & 27 & .252 & & \\
\hline & Total & 9.467 & 29 & & & \\
\hline
\end{tabular}

For the Psychological factors the p- value is 0.037 which is less than 0.05 . Hence there is significant difference between departments when we consider psychological factors.For the Quality of work life the p- value is 0.025 which is less than 0.05. Hence there is significant difference between departments when we consider Quality of work life. For the Perceived Employee performance the p- value is 0.012 which is less than 0.05 . Hence there is significant difference between departments when we consider perceived employee performance.

\section{FINDINGS}

Since the cross tab results revealed that both the Null hypothesis are rejected, we accept the Alternate hypothesis in both cases. This means that

- Psychological factors have significant impact on QWL.

- QWL has significant impact on Perceived employee performance.

The ANOVA analyzing the existence of differences among departments in their psychological factors and Quality of Work Life the findings are
- There is significant difference between departments when we consider psychological factors.

- There is significant difference between departments when we consider Quality of work life.

- There is significant difference between departments when we consider perceived employee performance.

The performance of the employees is critical to the success of the organization and the perceived employee performance is influenced by the Quality of Work Life existing in the organization. The psychological makeup of the employee influences his acceptance of the Quality of work life provided by the organization.

\section{CONCLUSION}

The Performance of the employee depends upon the various QWL initiatives undertaken by the organization. The Psychological factors have impact on the Quality of work life as perceived by employees. Accordingly a proposed model has been developed. But whether these initiatives granted from the part of the organization is understood positively or rather taken in the right spirit by the individual employee depends upon his psychological makeup. Hence we can conclude that the quality of work life initiatives the organization offers should be those which are needed and perceivable by its employees and not just adopting any improvements.

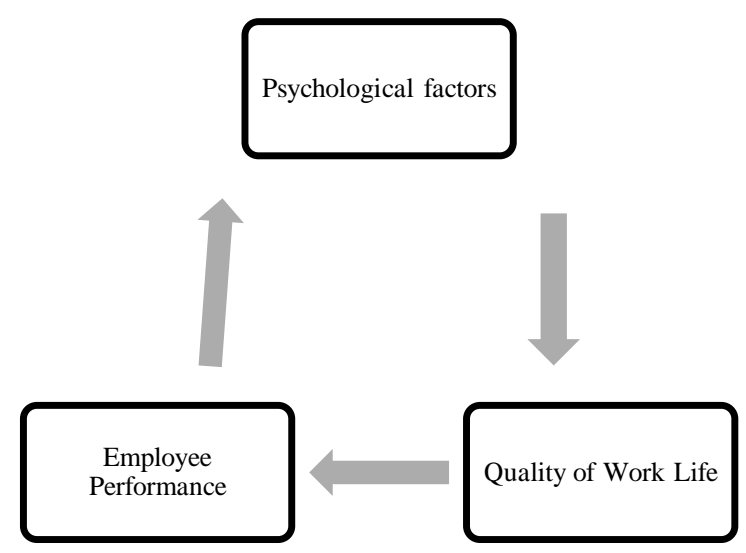

\section{REFERENCES}

[1] S. Havlovic, "Quality of work life and Human Resource Outcomes", Industrial Relations, Vol. 30, No.3, Pp. 469-479, 1991.

[2] D. Nadler, "Quality of work life: Perspectives and direction", Organizational Dynamics, Vol. 11, No.3, Pp. 20-30, 1983.

[3] R. Walton, “Quality of work life: What is it?”, Vol.11, Pp.11-21, 1973.

[4] Guna Seelan Rethinam and Maimunah Ismail, "A Basic concept on QWL”, European journal of Social Sciences, Vol. 7, No.1, 2008.

[5] Lau, Wong, Chan and Law, "Information Technology and Work Environment-Does it change the way People interact at work", Human System Management, Vol. 20, No.3, Pp. 267-280, 2001.

[6] Robbins P. Stephen, T. Judge and S. Sanghi, “Organizational Behavior”, Pearson Education, 2009.

[7] A.K. Sriviastava, "Perceived work Environment and Employees", Health, Psychological Studies, Vol.52, Pp. 345-347, 2007.

[8] D. Efarty, M. Sirgy and C.B. Claiborne, "The effects of personal alienation on organizational identification: quality of work life model", Journal of Business and Psychology, Vol. 6, No. 1, Pp. 57-58, 1991.

[9] D. Efarty and M. Sirgy, "The effects of quality of working life (QWL) on employee behavioural responses", Social Indicators Research, Vol. 22, No. 1, Pp. 31-47, 1990. 
[10] K.W. Chan and T.A. Wyatt, "Quality of Work Life: A Study of Employees in Shanghai, China”, Asia Pacific Business Review, Vol. 13, No. 4, Pp. 501-517, 2007.

[11] J.P. Campbell, R.A. McCloy, S.H. Oppler and C.E. Sager, “A theory of performance”, Personnel selection in organizations, Pp. 35-70, 1993.

[12] V. Indermun and M. Saheedbayat, "The job satisfaction-employee performance relationship: a theoretical perspective", International Journal of Innovative Research in Management, Vol. 11, No. 2, Pp. 1-9, 2013.

[13] R. Rai and S. Tripathi, "A Study on QWL and its effects on Job Performance", Journal of Management Sciences and Technology, Vol. 2, No. 2, Pp. 33-42, 2015. 